\title{
Logistics performance in South Africa
}

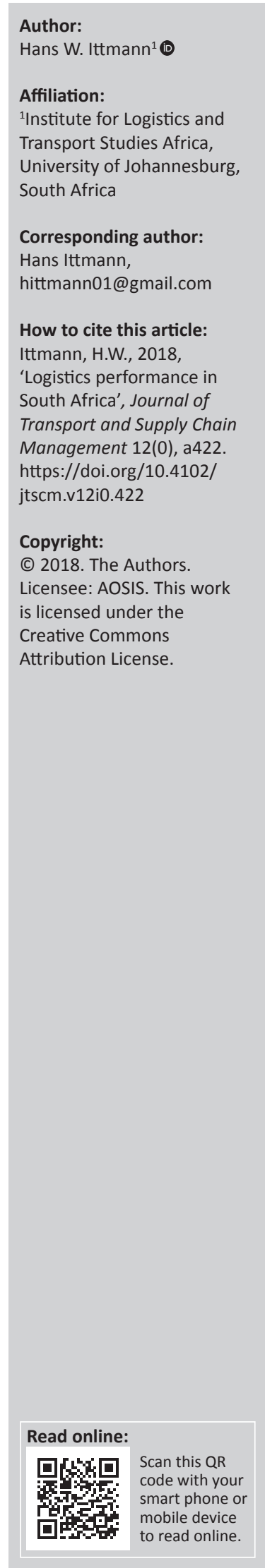

The logistics and supply chain management sector, worldwide, is changing dynamically and at a fast pace. Many examples of these can be cited, such as changes in demand, with the growth in e-commerce as an example, many disruptive technologies that are changing the face of various aspects of this sector, the increasing concerns and dangers surrounding cybersecurity as well as changes in government policies. The World Economic Forum (WEF 2017) identified the following eight megatrends that are likely to drive the future of logistics:

- Logistics skill shortages

- Restructuring global value chains

- Supply risk and recovery (resilience)

- Digital transformation of supply chains

- Sustainability of supply chains

- E-commerce driving demand chains

- Logistics property and infrastructure

- Collaborative business models. (n.p.)

It is within this changing environment that the logistics industry still needs to perform and remain competitive. The importance of logistics performance of the sector is critical for growth and integration within a country. It is the supply chains within an economy that provide access to what are needed to support commerce and sustain life. In addition, the sector plays an important role in facilitating trade within the country as well as across its borders. Given their vital importance, there is little appreciation of the complexity of supply chains - they only become noticeable when they are disrupted and become problematic. Logistics remains one of the core enablers of development. Against this background and given that the South African economy has not been performing well over the last number of years, this environment has put an enormous strain on the logistics and supply chain management industry in the country. Nevertheless, the sector has endeavoured to continue providing a quality and reliable service while keeping costs under control.

The sixth edition of the World Bank's Logistics Performance Index (LPI) was published recently (Arvis et al. 2018). The LPI is a view on trade logistics performance across most countries in the world as seen by logistics professionals that reside within a country as well as from outside of a country. The latest study results indicate that the South African logistics sector, in terms of the LPI, is still performing well although its ranking has decreased slightly from 20th out of 167 countries in the 2016 study, to being ranked 33rd out of 160 countries in the 2018 study. In the 2018 survey the World Bank also gave an aggregate LPI ranking and score for the period 2012-2018. South Africa's aggregated LPI ranking is 29th and LPI score 3.38. Figure 1 shows the LPI rankings and scores for South Africa since 2007, when the World Bank first published this study. The LPI ranking is just the rating in relation to the other countries using the LPI score. The latter is determined from the scores for the six main indicators used in the survey, where each one of these indicators is given a score out of five. The LPI score is also the most important indicator as it is more accurate and gives a better basis for comparison. Over the period of 11 years, there has not been much change in the LPI for South Africa, indicating that the overall logistics performance of the country has remained relatively stable over this period. In the 2018 survey, like in most of the other surveys, South Africa also features in the top ten of the top performing upper-middleincome economies, with China (3.61) and Thailand (3.41) ahead of South Africa in this group.

In the African context, South Africa has been consistently the top performing country. Table 1 shows the countries that follow South Africa for each of the six editions of the survey. South Africa remains way ahead of these countries, while it is noticeable that except in one instance the countries in second place vary from survey to survey, an indication of how volatile things are in the rest of Africa.

The six indicators that are used to determine the LPI scores for South Africa, for each of the surveys, are given in Table 2. The six indicators are:

- Customs

- Infrastructure 


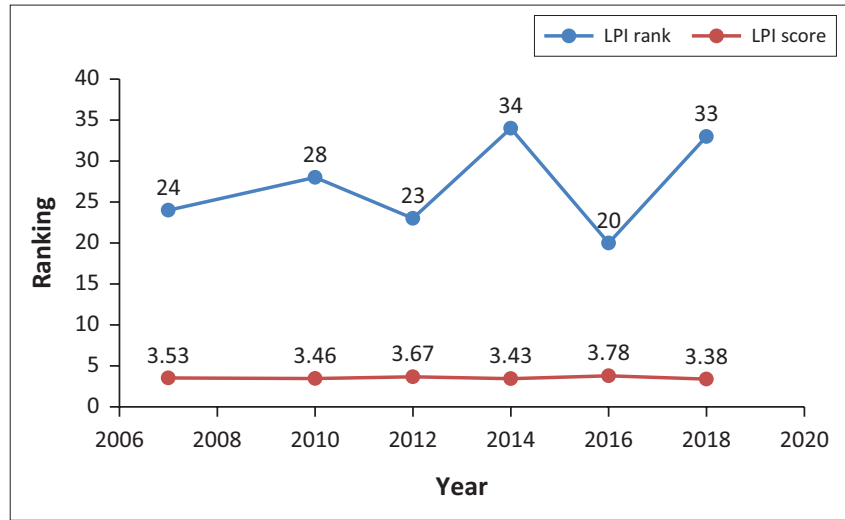

Source: Adapted from Arvis, J.-F., Mustra, M.A., Panzer, J., Ojala, L. \& Naula, T., 2007, Connecting to compete - Trade logistics in the global economy: The logistics performance index and its indicators, World Bank, Washington, DC; Arvis, J.-F., Mustra, M.A., Ojala, L., Shepherd, B. \& Saslavsky, D., 2010, Connecting to compete - Trade logistics in the global economy: The logistics performance index and its indicators, World Bank, Washington, DC; Arvis, J.-F., Mustra, M.A., Ojala, L., Shepherd, B. \& Saslavsky, D., 2012, Connecting to compete - Trade logistics in the global economy: The logistics performance index and its indicators, World Bank, Washington, DC; Arvis, J.-F., Saslavsky, D., Ojala, L., Shepherd, B. Busch, C. \& Raj, A, 2014, Connecting to compete - Trade logistics in the global economy: The logistics performance index and its indicators, World Bank, Washington, DC; Arvis, J.F., Saslavsky, D., Ojala, L., Shepherd, B., Busch, C., Raj, A. et al., 2016, Connecting J.F., Saslavske, D., Ojala, L, Shepherd, B.. Busch, C. Raj, A. et al. 2016, Connecting its indicators, World Bank, Washington, DC; Arvis, J.-F., Ojala, L., Wiederer, C., Shepherd, B., Raj, A., Dairabayeva, K. et al., 2018, Connecting to compete - Trade logistics in the global economy: The logistics performance index and its indicators, World Bank Washington, DC

LPI, logistics performance index.

FIGURE 1: World Bank logistics performance ranking and score for South Africa for the period 2007-2018.

TABLE 1: African countries that are ranked immediately behind South Africa.

\begin{tabular}{llcc}
\hline Year & Country & LPI ranking & LPI score \\
\hline 2007 & São Tomé and Principe & 57 & 2.86 \\
2010 & Tunisia & 61 & 2.84 \\
2012 & Tunisia & 41 & 3.17 \\
2014 & Egypt & 62 & 2.97 \\
2016 & Kenya & 42 & 3.33 \\
2018 & Côte d'lvoire & 50 & 3.08 \\
\hline
\end{tabular}

Source: Adapted from Arvis, J.-F., Mustra, M.A., Panzer, J., Ojala, L. \& Naula, T., 2007, Connecting to compete - Trade logistics in the global economy: The logistics performance index and its indicators, World Bank, Washington, DC; Arvis, J.-F., Mustra, M.A., Ojala, L., Shepherd, B. \& Saslavsky, D., 2010, Connecting to compete - Trade logistics in the global economy: The logistics performance index and its indicators, World Bank, Washington, DC; Arvis, J.-F., Mustra, M.A., Ojala, L., Shepherd, B. \& Saslavsky, D., 2012, Connecting to compete - Trade logistics in the global economy: The logistics performance index and its indicators, World Bank, Washington, DC; Arvis, J.-F., Saslavsky, D., Ojala, L., Shepherd, B. Busch, C. \& Raj, A. 2014, Connecting to compete - Trade logistics in the global economy: The logistics performance index and its indicators, World Bank. Washington, DC; Arvis, J. $F$, Saslavsky, D., Ojala, L, Shepher J.F., Saslavsky, D., Ojala, L, Shepherd, B., Busch, C. Raj, A. et al., 2016, Connecting to compete - Trade logistics in the global economy: The logistics performance inde its indicators, World Bank, Washington, DC, Arvis, J.-F., Ojala, L., Wiederer, C., Shepherd, B., Raj, A., Dairabayeva, K. et al., 2018, Connecting to compete - Trade logistics in the global economy: The logistics performance index and its indicators, World Bank, Washington, DC.

LPI, logistics performance index.
- International shipments

- Logistics quality and competence

- Tracking and tracing

- Timeliness.

Here too there are no major changes over the entire timeperiod. However, every single indicator gives a clear and important indication of how well the logistics sector measures against, and is accomplishing, the various logistic aspects. The 2018 survey does, nevertheless, show some elements of concern. Five of the indicators, international shipments excluded, have LPI rankings in the 30s, each with a LPI score that is the lowest ever in four of the five cases. If these are trends that will continue in the future, there is reason for the sector to be worried. In general, however, as shown in Table 2, the South African logistics and supply chain management sector has clearly been consistent, logistics friendly and its performance correlates strongly with a high quality of service over the 11-year period. Added to this, from analysis performed by the World Bank in the last survey, South Africa is in terms of its gross domestic product (GDP) per capita, or income, one of the top performers, outperforming most of its income group peers (Arvis et al. 2018). The performance of the logistics sector in South Africa has remained at a high level and there is no reason why this cannot be maintained in future notwithstanding the 'weaker' performance in 2018.

There is one area in South Africa, which is closely linked to the logistics sector, that is a concern and it is the delivery of mail by the South African Post Office. The movement of mail from points of origin to the ultimate receivers of the postal items are 'special' types of supply chains but no different from any other supply chain. There are regularly complaints in newspapers, in the media and on other forums about the lack of a proper service, and even a total lack of service, by the South African Post Office. The examples of complaints include the following: timely delivery is totally lacking; the service is not reliable as some items are never delivered and are assumed lost; customer service is terrible and visibility in the supply chain, that is, tracking and tracing of registered items, is bad and so on. These are all hearsay and possibly 'emotional' statements by individuals. However, an international scientific study gives a clearer picture of the state of South Africa's postal service.

TABLE 2: The scores of South Africa for the six indicators 2007-2018.

\begin{tabular}{|c|c|c|c|c|c|c|c|c|c|c|c|c|}
\hline \multirow[t]{2}{*}{ Year } & \multicolumn{2}{|c|}{ Customs } & \multicolumn{2}{|c|}{ Infrastructure } & \multicolumn{2}{|c|}{ International shipments } & \multicolumn{2}{|c|}{ Logistics quality and competence } & \multicolumn{2}{|c|}{ Tracking and tracing } & \multicolumn{2}{|c|}{ Timeliness } \\
\hline & Rank & Score & Rank & Score & Rank & Score & Rank & Score & Rank & Score & Rank & Score \\
\hline 2007 & 27 & 3.22 & 26 & 3.42 & 22 & 3.56 & 25 & 3.54 & 18 & 3.71 & 31 & 3.78 \\
\hline 2010 & 31 & 3.22 & 29 & 3.42 & 31 & 3.26 & 25 & 3.59 & 24 & 3.73 & 57 & 3.57 \\
\hline 2012 & 26 & 3.35 & 19 & 3.79 & 20 & 3.50 & 24 & 3.56 & 16 & 3.83 & 20 & 4.03 \\
\hline 2014 & 31 & 3.19 & 29 & 3.40 & 27 & 3.45 & 24 & 3.59 & 29 & 3.53 & 30 & 3.87 \\
\hline 2016 & 18 & 3.60 & 21 & 3.78 & 23 & 3.62 & 22 & 3.75 & 17 & 3.92 & 24 & 4.02 \\
\hline 2018 & 34 & 3.17 & 36 & 3.19 & 22 & 3.51 & 39 & 3.19 & 35 & 3.41 & 34 & 3.74 \\
\hline
\end{tabular}

Source: Adapted from Arvis, J.-F., Mustra, M.A., Panzer, J., Ojala, L. \& Naula, T., 2007, Connecting to compete - Trade logistics in the global economy: The logistics performance index and its indicators, World Bank, Washington, DC; Arvis, J.-F., Mustra, M.A., Ojala, L., Shepherd, B. \& Saslavsky, D., 2010, Connecting to compete - Trade logistics in the global economy: The logistics performance index and its indicators, World Bank, Washington, DC; Arvis, J.-F., Mustra, M.A., Ojala, L., Shepherd, B. \& Saslavsky, D., 2012, Connecting to compete - Trade logistics in the global performance index and its indicators, World Bank, Washington, DC; Arvis, J.-F., Mustra, M.A., Ojala, L., Shepherd, B. \& Saslavsky, D., 2012, Connecting to compete - Trade logistics in the global
economy: The logistics performance index and its indicators, World Bank, Washington, DC; Arvis, J.-F., Saslavsky, D., Ojala, L., Shepherd, B., Busch, C. \& Raj, A., 2014, Connecting to economy: The logistics performance index and its indicators, World Bank, Washington, DC; Arvis, J.-F., Saslavsky, D., Ojala, L., Shepherd, B., Busch, C. \& Raj, A., 2014, Connecting to
compete - Trade logistics in the global economy: The logistics performance index and its indicators, World Bank, Washington, DC; Arvis, J.-F., Saslavsky, D., Ojala, L., Shepherd, B., Busch, C., Raj, A. et al., 2016, Connecting to compete - Trade logistics in the global economy: The logistics performance index and its indicators, World Bank, Washington, DC; Arvis, J.-F., Ojala, L., Raj, A. et al., 2016, Connecting to compete - Trade logistics in the global economy: The logistics performance index and its indicators, World Bank, Washington, DC; Arvis, J.-F., Ojala, L.,
Wiederer, C., Shepherd, B., Raj, A., Dairabayeva, K. et al., 2018, Connecting to compete - Trade logistics in the global economy: The logistics performance index and its indicators, World Bank, Wiederer, C., Shep
Washington, DC. 
TABLE 3: Integrated Index for Postal Development ranking and scores for South Africa and the two top African countries.

\begin{tabular}{llccc}
\hline Year & Country & Rank & Score & Change from 2016 \\
\hline 2016 & Mauritius & 33 & 60.10 & - \\
& Nigeria & 49 & 52.62 & - \\
& South Africa & 66 & 42.99 & - \\
2018 & Tunisia & 49 & 51.90 & 5.93 \\
& Nigeria & 51 & 50.86 & -1.36 \\
& South Africa & 88 & 33.34 & -9.65 \\
\hline
\end{tabular}

Source: Adapted from Boffa, M., De Borba, F. \& Piotrowski, L., 2018, Postal developmen report 2018 - Benchmarking a critical infrastructure for sustainable development, Universal Postal Union, Berne, Switzerland; Universal Postal Union (UPU), 2016, Integrated Index for Postal Development (2IPD) - 2016 results, Universal Postal Union, Berne, Switzerland

The Universal Postal Union (UPU) is an international body with its headquarters in Berne, Switzerland, with 192 member countries. The UPU is the primary forum for cooperation between postal sector players and it aims to ensure a truly universal network of up-to-date products and services. In 2016, the UPU published the Integrated Index for Postal Development (2IPD), which is a composite index providing an overview of postal development around the world, with the results for 2016 covering 170 countries (UPU 2016). It is very similar to the LPI of the World Bank but aimed at postal services. In the case of the 2IPD, there are four main components that are measured, namely reliability, reach, relevance and resilience. These four components represent the challenges that the postal sector worldwide is facing owing, in particular, to the growing spread of e-commerce. The study was repeated in 2018 (Boffa, De Borba \& Piotrowski 2018) with 173 countries. Table 3 gives the results for South Africa as well as the two top African countries for the two respective years.

As input data to determining the 2IPD, the UPU used its data, including postal big data - over 3 billion tracking records checked and analysed - official UPU statistics and key UPU surveys (UPU 2016). This is a truly comprehensive study and the UPU believes the results obtained relied on 'the greatest data integration ever conducted to measure the development of postal services on a global scale'. In their analysis, the UPU determines performance sub-scores $(0-100)$ for the four key indicators, or the four dimensions of postal development: reliability, reach, relevance and resilience. Using these scores, the UPU then determines a benchmarking performance score and the top-ranked country is given a score of 100 and the scores of the lower ranked countries are given as a percentage of the top-ranked country's score. In 2016, for example, South Africa's 2IPD score was thus $42.99 \%$ of that of the top-ranked country,
Switzerland (UPU 2016). The numbers in Table 3 speak for themselves. It does not paint a rosy picture of the South African Post Office.

There has been a significant decrease in the 2IPD score for South Africa over the 2-year period. The UPU interprets a score between 25 and 50 as being 'a more intermediate level of performance in the low range, or lower middle performers'. If the score falls below 25, the country's postal development is 'closer to the worst absolute performer than to the intermediate one' (Boffa et al. 2018). In the 2018 survey, South Africa is close to this! In addition, this performance is not in line with the rest of the logistics industry in South Africa as depicted by the World Bank's LPI study.

Postal services, all over, are under pressure and need to diversify - something which post offices worldwide have already embarked on, years ago. However, the UPU results show that postal service providers need to improve their operational efficiency, increase their global connectivity, diversify further and adapt their business models to the dynamic, changing environment. One could add to this that, and applied specifically to South Africa, the logistics services should be reliable, predictable, and there should be total and transparent visibility in the supply chains, and furthermore excellent customer service!

\section{References}

Arvis, J.-F., Mustra, M.A., Panzer, J., Ojala, L. \& Naula, T., 2007, Connecting to compete Trade logistics in the global economy: The logistics performance index and its indicators, World Bank, Washington, DC.

Arvis, J.-F., Mustra, M.A., Ojala, L., Shepherd, B. \& Saslavsky, D., 2010, Connecting to compete - Trade logistics in the global economy: The logistics performance index and its indicators, World Bank, Washington, DC.

Arvis, J.-F., Mustra, M.A., Ojala, L., Shepherd, B. \& Saslavsky, D., 2012, Connecting to compete - Trade logistics in the global economy: The logistics performance index and its indicators, World Bank, Washington, DC.

Arvis, J.-F., Saslavsky, D., Ojala, L., Shepherd, B., Busch, C. \& Raj, A., 2014, Connecting to compete - Trade logistics in the global economy: The logistics performance index and its indicators, World Bank, Washington, DC

Arvis, J.-F., Saslavsky, D., Ojala, L., Shepherd, B., Busch, C., Raj, A. et al., 2016, Connecting to compete - Trade logistics in the global economy: The logistics performance index and its indicators, World Bank, Washington, DC.

Arvis, J.-F., Ojala, L., Wiederer, C., Shepherd, B., Raj, A., Dairabayeva, K. et al., 2018 Connecting to compete - Trade logistics in the global economy: The logistics performance index and its indicators, World Bank, Washington, DC.

Boffa, M., De Borba, F. \& Piotrowski, L., 2018, Postal development report 2018 Benchmarking a critical infrastructure for sustainable development, Universal Postal Union, Berne, Switzerland.

Universal Postal Union (UPU), 2016, Integrated Index for Postal Development (2IPD) - 2016 results, Universal Postal Union, Berne, Switzerland.

World Economic Forum (WEF), 2017, Supply chain and transport - Explore the latest strategic trends, research and analysis, viewed 25 September 2018, from https:// toplink.weforum.org/knowledge/insight/a1Gb0000000pTDoEAM/explore/ summary 